
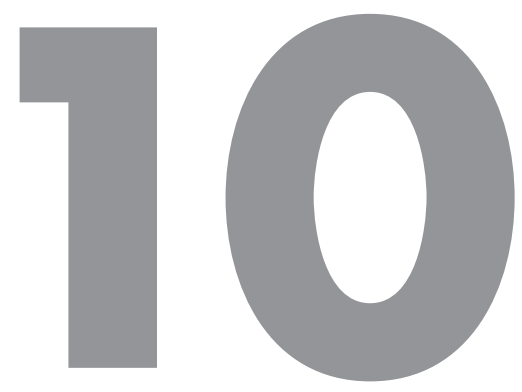

\title{
LITISCONSÓRCIO NECESSÁRIO OU FACULTATIVO, TERMO INICIAL E FINAL DO PRAZO DA AÇÃO RESCISÓRIA
}

Peculiar é o processo em que figuram duas ou mais partes em litisconsórcio, uma manifesta a ciência do trânsito em julgado nos autos e outra aguarda a intimação pela imprensa. Haveria prazo comum ou o prazo seria individual para o ajuizamento da ação rescisória? E mais, na ação rescisória haveria obrigatoriedade de figurarem todos os réus e todos os autores da ação originária, em que foi proferida a decisão atacada? Parece, nessa vertente litisconsorcial, com partes intimadas por vias distintas, que o prazo deverá ser computado distintamente, da comprovação da ciência de cada parte nos autos. ${ }^{1}$ Isso porque a antecipação da ciência de uma parte não poderá prejudicar o direito das demais partes, ainda que em litisconsórcio necessário. Observe-se que, nesse regime litisconsorcial, haverão todos os réus e autores da ação rescindenda que tomar parte na exordial rescisória, sob pena de nulidade dos atos decisórios que vierem a ser proferidos. ${ }^{2}$

1 CINTRA, Antônio Carlos de Araújo; GRINOVER, Ada Pellegrini; DINAMARCO, Cândido Rangel. Teoria geral do processo. 7. ed. São Paulo: RT, 1990. p. 273.

2 CRUZ, José Raimundo Gomes da. Pluralidade de partes e intervenção de terceiros. São Paulo: RT, 1991. p. 27. 
Quanto à obrigatoriedade de integração da lide da totalidade das partes da ação primitiva, a indagação comporta duas respostas. Se for a ação originária regida pelo litisconsórcio unitário, a resposta é positiva. ${ }^{3}$ Ocorre a decadência da rescisória se a ação não for proposta contra todos os litisconsortes necessários, dentro do prazo de dois anos. ${ }^{4}$ Se for caracterizada pelo litisconsórcio não unitário, a resposta revela-se negativa, ou seja, não haverá obrigatoriedade da presença de todos os autores e réus da ação originária na formação da ação rescisória, uma vez que se admite a rescisão parcial - exegese do art. 113 do CPC/2015. ${ }^{5}$

3 “Acontece que o litisconsórcio unitário nem sempre é necessário, bastando lembrar os casos de condôminos que reivindicam a coisa comum e de credores solidários frente à cobrança da dívida única. Agindo em conjunto ou separadamente, o resultado será uniforme para todos os interessados, mas o litisconsórcio não é obrigatório”. (THEODORO JÚNIOR, Humberto. Curso de direito processual civil. 18. ed. Rio de Janeiro: Forense. 1996. v. I. p. 108). No mesmo sentido: "Não se confundindo o litisconsórcio unitário com o necessário pode haver um sem que haja o outro. Tanto pode haver litisconsórcio necessário não unitário (é o que se verifica no processo de usucapião), como litisconsórcio facultativo unitário (no caso, por exemplo, em que apenas alguns acionistas movem ação para anular deliberação da assembleia geral)”. (MARQUES, José Frederico. Manual de direito processual civil. 9. ed. São Paulo. Saraiva. 1982. v. 1. p. 274).

4 STJ - AR 2009/PB, $1^{a}$ Seção, Rel. Ministro Teori Albino Zavascki, DJ 03.05.2004. Vide também: STJ - EREsp 676.159/MT, Corte Especial, Rel. Ministro Nancy Andrighi, DJe 30.03.2011.

5 "Ilegitimidade ad causam - Ação rescisória - Caso em que nem todos aqueles que figuraram como parte na relação processual originária devem, necessariamente, estar presentes na ação rescisória - Circunstância que dependerá do tipo de litisconsórcio formado originalmente, bem como do alcance objetivo e subjetivo do juízo rescindente e do juízo rescisório - Corré 'Fachini \& Kitakawa Ltda.' que não figurou como litisconsorte necessária no processo originário e que não será atingida nem pela eventual cassação das sentenças originárias, nem pelo suposto novo julgamento a ser proferido - Inexistência de justificativa para que a mencionada corré permaneça no polo passivo da demanda em exame - Extinção da ação rescisória, quanto à corré 'Fachini \& Kitakawa Ltda.', sem resolução de mérito, com base no art. 267, VI, do CPC.” (...) "Ação rescisória - Violação de literal disposição de lei - Sentença rescindenda que, sem decidir a denunciação da lide, condenou o denunciado, solidariamente com o denunciante 'Banco Itaú S.A.', a pagar ao autor da ação originária indenização por danos morais - Impossibilidade de se admitir a condenação solidária entre o denunciante e o denunciado, em razão da qualidade de litisconsorte que este último teria assumido perante o primeiro - Denunciado que somente poderia ser considerado 'litisconsorte' do denunciante, caso aceitasse e contestasse o pedido, o que não ocorreu na hipótese em tela - Art. 75, I, do CPC - Manifesta a violação ao estatuído no art. 76 do CPC." (TJSP - Ação Rescisória. 9006960-38.2008.8.26.0000, Comarca: Monte Azul Paulista, 23 ${ }^{\mathrm{a}}$ Câmara de Direito Privado, Rel. Des. José Marcos Marrone, julgado em 25.11.2009, registro 11.01.2010). Correspondem aos arts. 267, 75 e 76 do CPC/1973 os arts. 485, 128 e 129 do CPC/2015. 
Nesse sentido, se a demanda originária, por mera conveniência das partes, for proposta em uma única peça e, por conseguinte, reunida em um único processo, não pode desnaturar o desfecho do processo, devendo seguir o mesmo resultado se fossem propostas ações distintas. Nas ações distintas, se caberiam ações rescisórias distintas, portanto, se reunidas as demandas, mantém-se o direito ao cabimento das ações rescisórias distintas. É que a Súmula 401 do STJ garante o prazo mais alargado, contado até o último recurso, mas não veda a propositura desde logo da ação rescisória para este caso, admitindo-se uma propositura antecipada, em face das características da demanda. Destaque-se que, neste caso, não há como se falar em geração de efeitos diversos daquele que seria obtido naturalmente pela parte, se optasse pela ação individual. Aliás, a aplicação ab initio do princípio da economia processual em hipótese alguma implicará prejuízo à parte. Portanto, verifica-se que impera o mesmo regime para ações reunidas em uma única peça ou se propostas separadamente, nos casos que comportarem o litisconsórcio não unitário. ${ }^{6}$

Ainda, quando houver relação de denunciação da lide (ex.: seguradora), via de regra, não pode o denunciado ser condenado diretamente em prol do autor da ação principal, ou de maneira solidária com o réu denunciante, visto que, no mais das vezes, ${ }^{7}$ nenhuma relação jurídica existirá entre o denunciado e o autor. O

6 A doutrina já acentuou que, uma vez "não constituindo objeto do julgamento uma só é única situação jurídica substancial incindível, o processo tende a vários provimentos 'somados em uma sentença formalmente única' - e isso será assim ainda quando haja algum pronunciamento incidenter tantum acerca de uma relação incindível (...). É o caso de várias vítimas de um só acidente rodoviário postulando condenação da mesma empresa ao ressarcimento; também o de uma ação de cobrança movida ao mutuário e ao fiador; ou uma de servidores à Fazenda Pública, visando a vantagens análogas. Em casos assim (...) o que se tem é uma pluralidade jurídica de demandas, também unidas só formalmente; cada um dos litisconsortes é parte legítima apenas com referência àquela porção do objeto do processo que lhe diz respeito, e, consequentemente, entende-se que seu petitum se reduz a essa parcela. Trata-se efetivamente de um cúmulo de demandas, não só subjetivo mas também objetivo, na medida em que à pluralidade de sujeitos corresponde uma soma de pedidos, todos eles amalgamados no complexo objeto que esse processo tem”. (DINAMARCO, Cândido Rangel. Litisconsórcio. 8. ed. São Paulo: Malheiros, 2009. p. 85-86).

7 "Não há relação entre o autor principal e o denunciado (RJTJESP 111/63, RF 297/242), que não pode ser condenado solidariamente com o réu denunciante (RT 629/216, 679/122). Improcedente a ação, fica prejudicada a denunciação, sem possibilidade de condenação direta do denunciado, em lugar do réu denunciante (RSTJ 5/363, maioria, RF 298/198, RJTAMG 30/153). Assim, não pode a sentença julgar a ação principal procedente contra o denunciado e improcedente contra o réu denunciante ( $R T$ 713/187, RJTJESP 111/63, RF 284/278, JTA 97/121), ou excluir da lide o réu denunciante (RJTAMG 22/238). Menos ainda poderá a 
mesmo raciocínio vale quando o litisdenunciante é o autor. Nesse sentido, também não se colhe automática formação do litisconsórcio ${ }^{8}$ na ação rescisória. ${ }^{9}$

Por esses argumentos, é fácil ver que não é requisito da ação rescisória a existência de litisconsórcio obrigatório entre autores e réus da ação primitiva. ${ }^{10}$ Não há vedação legal a que, no caso concreto, possa o tribunal vir a decidir pela rescisão parcial, atingindo apenas as partes que figuraram na ação rescisória, muito embora outras constantes da ação originária não tenham integrado a lide rescisória. Em verdade, a ação rescisória se submete à regra geral dos arts. 114 e 116 do CPC/2015, segundo a qual se admite o litisconsórcio necessário, no caso de o decreto rescisório atingir igualmente a todas as partes do processo primitivo ou facultativo previsto no art. 113 do CPC/2015, dependendo de a situação comportar rescisão parcial, em favor de uma ou algumas partes da ação originária em que se proferiu a decisão impugnada. ${ }^{11}$ Em consequência, também o litisconsorte

sentença condenar diretamente o denunciado 'a compor os prejuízos reclamados pelo autor, sem apreciação da lide principal' (RSTJ 25/426, JTJ 174/49)." (NEGRÃO, Theotonio; GOUVÊA, José Roberto Ferreira. Código de Processo Civil e legislação processual em vigor, 39. ed., art. $76: 6$, p. 211).

8 Devem estar presentes os requisitos, e a solidariedade não se presume. Veja-se a seguinte ementa: "Uma vez aceita a denunciação da lide e apresentada contestação quanto ao mérito da causa, o denunciado assume a condição de litisconsorte do réu. Possibilidade de condenação direta e solidária do terceiro interveniente ao pagamento da indenização. (...) Decisão agravada mantida por seus próprios e jurídicos fundamentos, uma vez que as razões do regimental trouxeram a simples reiteração dos argumentos anteriormente expendidos. Agravo regimental desprovido”. (STJ - AgRg no REsp 1.172.835/PR, Rel. Ministro Paulo de Tarso Sanseverino, $3^{\text {a }}$ Turma, julgado em 22.02.2011, DJe 28.02.2011).

9 A esse respeito, elucidativos os ensinamentos da doutrina: "A condenação disciplinada no art. 76 do Código de Processo Civil é imposta ao denunciado e concedida exclusivamente em favor do denunciante. Não se admite a condenação do denunciado em favor do autor da demanda principal, porque nenhuma demanda moveu este àquele e sequer existia qualquer relação jurídica material que os interligasse (o terceiro era parte ilegítima para a demanda proposta pelo autor). Ainda que a condenação direta apresentasse vantagens, só por disposição expressa de lei ela poderia ser admitida”. (DINAMARCO, Cândido Rangel. Instituições de direito processual civil, 2001, v. II, n. 607, p. 408).

10 A existência de litisconsórcio na ação originária nem sempre imporá a formação de litisconsórcio na ação rescisória. É que "o litisconsórcio necessário somente ocorrerá se a sentença rescindenda não comportar rescisão subjetivamente parcial, mas apenas integral, para todas as partes envolvidas na ação originária”. (MEDINA, José Miguel Garcia. Novo Código de Processo Civil comentado, p. 1392).

11 "Processual Civil. Ação rescisória. Regime de litisconsórcio. (...) 1. Segundo dispõe o art. 47 do CPC, 'Há litisconsórcio necessário, quando, por disposição de lei ou pela natureza da 
facultativo da ação primitiva não pode legitimamente querer integrar a ação rescisória depois de decorrido o prazo de dois anos (art. 975 do CPC/2015), pois restará consumado o prazo decadencial. ${ }^{12}$

Por fim, dentro do capítulo específico de uma sentença complexa, podem-se comportar partes em litisconsórcio necessário, muito embora seja facultativo com relação a outro capítulo. ${ }^{13-14}$

Nesse caso, quando a ação rescisória objetivar atacar apenas um ou alguns capítulos da sentença, o litisconsórcio deverá ser analisado em cada capítulo, ${ }^{15}$ e,

relação jurídica, o juiz tiver de decidir a lide de modo uniforme para todas as partes'. Relativamente à ação rescisória, não havendo disposição legal a respeito, o litisconsórcio necessário somente ocorrerá se a sentença rescindenda não comportar rescisão subjetivamente parcial, mas apenas integral, para todas as partes envolvidas na ação originária. 2. Tratando-se de sentença proferida em ação proposta mediante litisconsórcio ativo facultativo comum, em que há mera cumulação de demandas suscetíveis de propositura separada, é admissível sua rescisão parcial, para atingir uma ou algumas das demandas cumuladas. Em casos tais, qualquer um dos primitivos autores poderá promover a ação rescisória em relação à sua própria demanda, independentemente da formação de litisconsórcio ativo necessário com os demais demandantes; da mesma forma, nada impede que o primitivo demandado promova a rescisão parcial da sentença, em relação apenas a alguns dos primitivos demandantes, sem necessidade de formação de litisconsórcio passivo necessário em relação aos demais.” (STJ - REsp 1.111.092/MG, Rel. Ministro Teori Albino Zavascki, $1^{\text {a }}$ Turma, julgado em 28.06.2011, DJe 01.07.2011).

12 A mesma ementa referenciada dá conta de que "em ação rescisória, não é cabível a inclusão de litisconsorte passivo facultativo após o transcurso do prazo de dois anos previsto no art. 495, consumado que está, em relação a ele, o prazo de decadência”. (Recurso especial n. 1.111.092/ MG, conforme nota supra).

13 FUX, Luiz. Curso de direito processual civil. 4. ed. Rio de Janeiro: Forense, 2008. v. I. p. 691.

14 "No processo civil brasileiro, a teoria adotada é a utilizada por Liebman e transplantada para a nossa realidade por Cândido Rangel Dinamarco em sua obra Capítulos de sentença. A única diferença relevante, que é relativa aos capítulos processuais, pois Dinamarco os diferencia em extintivos ou não e Liebman não realizava tal subdivisão. Assim, para o presente trabalho, capítulo de sentença são as decisões autônomas contidas no dispositivo da decisão”. (PEIXOTO, Ravi. Ação rescisória e capítulos de sentença: a análise de uma relação conturbada a partir do CPC/2015. In: DIDIER JR., Fredie (coord.); MACÊDO, Lucas Buril de; PEIXOTO, Ravi; FREIRE, Alexandre. Novo CPC - doutrina selecionada, v. 6: processo nos tribunais e meios de impugnação às decisões judiciais. Salvador: JusPodivm, 2016. p. 224).

15 “Caso tenha se formado litisconsórcio simples na ação originária, poderá não ser obrigatória a formação de litisconsórcio passivo na ação rescisória. P. ex., restringindo-se o objeto da ação rescisória a um capítulo de decisão (ou a algum deles), poderá não ser necessária a formação de 
se existente a situação de uniformidade da decisão para parcela dos demandantes, estes deverão integrar a ação rescisória, ${ }^{16}$ uma vez configurado o litisconsórcio necessário parcial em face da unitariedade em relação à ação primitiva. ${ }^{17}$

litisconsórcio em relação a todos aqueles a quem o capítulo impugnado não diga respeito (nesse sentido, cf. STJ, AR 5.064/ES, rel. Min. Luiz Felipe Salomão, 2. a S., j. 11.02.2015).” (MEDINA, José Miguel Garcia. Novo Código de Processo Civil comentado, p. 1392).

16 "A rescisão pode ser realmente de parte da decisão contra todos e não pode ser de toda a decisão contra parte dos litigantes. Mas (...) a seguinte hipótese [também é] possível (...) a rescisão pode ser de parte da decisão contra parte dos litigantes." (COSTA, Dilvanir José da. Do litisconsórcio necessário em ação rescisória. Revista de Processo, São Paulo: RT, n. 30, 1983. p. 280-281).

17 "O Código não contém disposição expressa a respeito da legitimação passiva para a ação rescisória. O princípio geral, parece-nos, é o de que devem integrar o contraditório todos aqueles que eram partes no feito anterior, ao ser proferida a sentença (lato sensu) rescindenda. (...) Ressalve-se que, se se tratar de sentença objetivamente complexa, e o pedido de rescisão visar apenas um (ou alguns) dos distintos capítulos, será desnecessária a citação daquele(s) a quem, conquanto parte(s) no processo anterior, não diga(m) respeito o(s) capítulo(s) rescindendo(s). Assim, v.g., caso tenha havido denunciação da lide, e o denunciado queira rescindir a sentença na parte em que reconheceu, em face dele, o direito regressivo do denunciante, bastar-lhe-á, na rescisória, fazer citar este último. Análoga disciplina se observará se, no processo anterior, houve cumulação subjetiva de ações, com litisconsórcio sujeito ao regime comum, e só se pretende a rescisão no tocante a um (ou a alguns) dos litisconsortes.” (MOREIRA, José Carlos Barbosa. Comentários ao Código de Processo Civil. 12. ed. Rio de Janeiro: Forense, 2005. v. V: arts. 476 a 565. p. 173-174). 